\begin{tabular}{|ccc|}
\hline $\begin{array}{c}\text { JURNAL } \\
\text { INOVASI }\end{array}$ & $\begin{array}{c}\text { Jurnal Inovasi Teknologi Pendidikan } \\
\text { TEKNOLOGI } \\
\text { PENDIDIKAN }\end{array}$ & Volume 4, No 2, October 2017 (140-156) \\
Online: http://journal.uny.ac.id/index.php/jitp & | Pendidikan Indonesia \\
\hline \hline
\end{tabular}

\title{
STUDI ETNOGRAFI PENDIDIKAN PADA SMA NEGERI 6 YOGYAKARTA: KETAHANAN DAN KETIDAKTAHANAN BELAJAR KELOMPOK
}

\author{
Novi Trilisiana, Sugeng Bayu Wahyono \\ 1,2)Universitas Negeri Yogyakarta \\ trilisiana@gmail.com,bayu_wahyono@yahoo.com
}

\begin{abstract}
Abstrak
Penelitian ini bertujuan mengungkapkan kontribusi ketahanan dan ketidaktahanan belajar kelompok siswa SMA Negeri 6 Yogyakarta. Penelitian ini merupakan penelitian kualitatif yang mengacu pada penelitian etnografi di sekolah. Pengumpulan data dilakukan melalui observasi terlibat, wawancara mendalam, dan dokumentasi. Data yang terkumpul dibuat ke dalam transkrip, pengkodean, serta pemunculan tema. Data dianalisis dengan menggunakan konsep dinamika kelompok dan belajar kooperatif. Hasil penelitian ini mengidentifikasi adanya dua kondisi belajar kelompok, dimana minoritas kelompok siswa menunjukkan ketahanan sedangkan mayoritas menunjukkan ketidaktahanan. Ketahanan belajar kelompok dapat tercipta karena adanya kesadaran kolektif, saling percaya, saling bekerja sama, dan tanggung jawab antar anggota. Ketidaktahanan belajar kelompok dapat tercipta karena adanya egosentrisme, sekadar formalitas, saling bersaing, dan pragmatisme belajar. Semakin cepat terjadinya transformasi dari faktor yang melemahkan kelompok kepada kepentingan kelompok, semakin lama ketahanan belajar kelompok, dan begitu sebaliknya.
\end{abstract}

Kata kunci: etnografi, dinamika kelompok, ketahanan, ketidaktahanan, belajar kelompok

\section{ETHNOGRAPHIC STUDY OF EDUCATION AT SMA NEGERI 6 YOGYAKARTA: THE DURABILITY AND NOT DURABILITY OF STUDY GROUPS}

\author{
Novi Trilisiana, Sugeng Bayu Wahyono \\ 1,2)Universitas Negeri Yogyakarta \\ trilisiana@gmail.com, bayu_wahyono@yahoo.com
}

\begin{abstract}
This article concerns a research aimed at revealing durability of study group contributions and contribution of the not durability of study groups at SMA Negeri 6 Yogyakarta. This study was qualitative research referring to the ethnography in school. The data were collected through participant observations, in-depth interviews, and documentation. The collected data were interpreted into transcript, coded, and thematized. The data were analyzed by using the concepts of group dynamics and cooperative learning. The results of the study identified two conditions of study groups that minority groups of students showed durable while the majority showed not durable. The durability of study groups could be created because there are a collective awareness, mutual trust, mutual cooperation and responsibility among the members. The not durability of study groups could be created because there are students' egocentrism, formality, competing and pragmatism in learning. The faster the transformation from the factors that weaken the group to the benefit of the group, the longer durability study groups, and vice versa
\end{abstract}

Keywords: ethnography, group dynamics, durability, not durability, study groups 


\section{Pendahuluan}

Belajar kelompok merupakan salah satu strategi pembelajaran yang mendukung pembelajaran aktif bagi siswa (Sanjaya, 2010, p. 128). Pembelajaran kelompok menarik untuk diamati karena siswa adalah manusia yang dalam memenuhi kebutuhannya tidak terlepas dari bantuan orang lain. Adanya fenomena bahwa manusia selalu memerlukan kehidupan berkelompok untuk memenuhi kebutuhannya, oleh Gibson (Munir, 2001, p. 9) dilalui terlebih dahulu dengan adanya kedekatan, daya tarik, kesamaan tujuan, dan alasan ekonomi. Sebab itulah, hampir tidak ada upaya seseorang individu yang tidak bersentuhan atau tidak memerlukan campur tangan orang lain (Munir, 2001). Dengan kata lain, kelompok dipandang sebagai medan yang memungkinkan setiap individu menjadi sistem yang saling terkait secara dinamis dan saling mempengaruhi satu sama lain dalam tanggung jawab sehingga tidak ada yang dapat eksis lebih lama manakala terpisah dari kelompok (Lewin, 1948).

Belajar kelompok adalah cara yang efektif dilakukan untuk meningkatkan hubungan, mengaktifkan partisipasi/keterlibatan di dalam diskusi dan menunjukkan pentingnya bekerja sama satu dengan yang lain secara lebih akrab (Wilson, 2014, p. 4). Sebab, menurut Michaelsen \& Sweet (2011, pp. 41-51) bahwa belajar kelompok memiliki unsur yang meliputi adanya pembagian kelompok yang merata, adanya pemahaman tanggung jawab tiap individu dalam kelompok, adanya umpan balik, dan adanya perancangan tugas berupa pembagian tugas dan peran yang jelas. Peran kelompok dengan variasi gender yang berbeda dapat diperhitungkan dalam peningkatan belajar kelompok (Adkinson, 2007).

Dalam jangka waktu tertentu, anggota yang sering terlibat dalam kelompok akan pandai mengasah keterampilan memecahkan masalah di dalam kelompok (Whitener, 2016; Varvarigou, 2016) dan memiliki pencapaian skor hasil belajar yang lebih tinggi (Acar \& Tarhan, 2007; Johnson, 2013; Foldnes, 2016). Para siswa yang aktif ketika mencari pengetahuan maupun memberikan solusi akan lebih sukses secara akademik daripada teman sebayanya yang lebih aktif secara sosial sedangkan siswa yang pasif menampilkan hasil akademik yang rendah (Shoval \& Shulruf, 2011). Keterampilan seperti mampu bekerja dalam tim, mampu memecahkan masalah, dan menguasai teknologi informasi, adalah kapasitas yang dibutuhkan di lapangan pekerjaan manapun (Barrow, Bradshaw \& Newton, 2001, p. 5).

Pelaksanaan pembelajaran di Indonesia, pada kenyataannya, mengacu pada Permendikbud Nomor 65 Tahun 2013 tentang Standar Proses Pendidikan Dasar dan Menengah yang dibagi menjadi tiga, yakni pendahuluan, inti, dan penutup (Kunandar, 2013, p.8). Peraturan tersebut mengatur tentang pemilihan pendekatan seperti tematik, saintifik, inkuiri, penyingkapan (discovery), dan atau Project Based Learning $(P B L)$, yang dapat disesuaikan dengan karakteristik kompetensi dan jenjang pendidikan. Pendekatan yang diatur tersebut mendorong tingkat satuan pendidikan untuk melaksanakan proses pembelajaran berbasis proyek maupun kelompok demi peningkatan kualitas pembelajaran. Seperti manfaat pendekatan $P B L$ yang dapat meningkatkan motivasi, kreativitas, dan pemahaman konsep (Pradipta \& Sofyan, 2015).

Guru memiliki peran yang penting dalam mewujudkan pembelajaran kelompok. Semboyan Sistem Among yang telah dirumuskan oleh Ki Hadjar Dewantara dapat membantu guru dalam mewujudkan pembelajaran kelompok yang aktif (Siswoyo, 2008, p. 171). Selain itu, pengalaman guru mengajar merupakan faktor penting dalam kesuksesan penerapan metode pembelajaran kelompok yang kooperatif (Williams, 2013, pp. 95-97). Kemampuan guru menciptakan suasana dimana, baik guru maupun siswa saling menghadapi tantangan dan membangun pengetahuan melalui kelompok yang saling berkolaborasi, menepis diskursus belajar sekadar transfer pe- 
ngetahuan (Burress \& Peters, 2015; Langer, Colton, \& Goff, 2003, p. 27).

Pembelajaran kelompok perlu menjadi tradisi yang biasa di dalam proses pembelajaran di sekolah. Siswa idealnya tidak lagi canggung mengungkapkan pendapatnya maupun berpikir kritis di dalam kelompok sesuai dengan tingkat perkembangan emosi-sosial mereka. Dapat diketahui bahwa tradisi belajar kelompok tentu memerlukan waktu yang relatif lama untuk membentuknya. Hal ini dapat menjadi suatu potensi masalah karena ketersediaan waktu belajar di sekolah terbatas. Belum lagi ketidak-kondusifan siswa dalam menjalankan peran sebagai anggota kelompok. Beberapa siswa boleh jadi mendominasi kelompok dan beberapa yang lainnya menarik diri sehingga tugas kelompok dikerjakan oleh hanya orang yang sama.

Saat studi dokumen dan observasi awal, peneliti menemukan di dalam Rencana Program Pembelajaran (RPP) SMA Negeri 6 Yogyakarta yang mencantumkan strategi belajar kelompok untuk mencapai tujuan pembelajaran. Hal ini menunjukkan bahwa faktanya, strategi belajar kelompok diterapkan di sekolah tersebut. Hal ini menjadi ketertarikan peneliti untuk mengetahui lebih dalam mengenai kualitas belajar dalam belajar kelompok di tengah gangguan seperti fenomena budaya titip nama, pembagian kerja yang tidak jelas, sistem evaluasi yang kurang relevan, dan gangguan lainnya yang dapat ditemukan saat penelitian.

Kelompok belajar yang tumbuh pesat diiringi pula dengan adanya kelompok yang memiliki kesamaan tujuan tetapi tidak berorientasi pada belajar yang postif. Tidak dapat dipungkiri adanya kelompok terselubung seperti geng sekolah yang menunjukkan eksistensi kelompok dengan tawuran dan aksi vandalisme. Belum lagi banyak bermunculan kelompok penggemar artis yang gandrung di kalangan siswa. Mereka berkelompok tetapi tidak didasarkan pada tujuan pembelajaran di sekolah dan bimbingan guru.

Belajar kelompok yang semula di sekolah sepatutnya dapat dilakukan dima- na saja dengan bimbingan siapa saja. Era digital ini menjadikan jaringan siswa semakin luas. Ada pemeo di kalangan masyarakat bahwa era digital dapat mendekatkan yang jauh dan sebaliknya, menjauhkan yang dekat. Era digital mampu memperpendek jarak dan menghemat waktu sehingga setiap orang dapat lebih mudah mendapatkan informasi.

Era digital tidak lepas membentuk pola kesenangan para pelajar di Indonesia. Rerata situs yang sering diakses adalah jejaring media sosial seperti, Facebook, Twitter, Instagram maupun fasilitas chatting seperti, Whatsapp, BBM, Telegram dan sebagainya. Mereka mengakses media sosial untuk kebutuhan eksistensi diri. Rerata akses situs yang berisi konten pembelajaran seperti e-learning masih lebih rendah dibandingkan situs jejaring sosial. Raphael, Bachen, \& Hernández-Ramos (2012) menemukan bahwa belajar kooperatif yang berkualitas dan dikemas ke dalam permainan (game) dapat meningkatkan pengetahuan maupun skil kewarganegaraan.

Belajar kelompok sebenarnya memberikan implikasi kemajuan (progress) dalam aspek kerja sama siswa ataukah belajar kelompok menjadi beban bagi perorangan siswa sehingga sebenarnya mengalami kemunduran (regress) pada aspek kerja sama antara para siswa. Dengan kata lain, belajar kelompok sudahkah benar-benar tahan atau hanya sekadar tugas kelompok yang membuat siswa seperti bekerja secara individual.

Belajar merupakan objek formal dalam bidang keilmuan Teknologi Pembelajaran yang dapat terjadi pada manusia, baik sebagai pribadi maupun yang tergabung di dalam organisasi (Miarso, 2009). Sepanjang masih terdapat masalah dalam pendidikan terutama kelas-kelas pembelajaran, sepanjang itu pula masih dibutuhkannya keilmuan Teknologi Pembelajaran. Permasalahanpermasalahan yang dapat ditemukan di dalam pelaksaan belajar kelompok dapat diteliti sehingga keilmuan Teknologi Pembelajaran menjadi berkembang, terutama terkait pada metode pembelajaran yang bersifat preskriptif. Oleh karena itu, belajar 
kelompok menjadi garapan keilmuan yang penting untuk diteliti.

Fenomena tersebut menjadi gambaran awal untuk melakukan studi mendalam tentang perilaku dan budaya yang berkaitan dengan seberapa besar ketahanan belajar kelompok yang dimiliki oleh siswa dan bagaimana kontribusi yang menjadi penyebab. Oleh sebab itu, diperlukan studi terhadap ketahanan belajar kelompok dalam rangka mengetahui kemampuan siswa untuk bertahan melakukan pembelajaran kelompok yang berorientasi pada belajar yang positif. Subjek studi adalah siswa SMA Negeri 6 Yogyakarta. Fokus penelitian dalam penelitian kualitatif ini mengenai praktik belajar kelompok di SMA N 6 Yogyakarta dan sejauh mana belajar kelompok dapat berdaya tahan beserta kontribusi yang mendukung. Berdasarkan uraian tersebut, penelitian ini bertujuan mengungkapkan kontribusi ketahanan dan ketidaktahanan belajar kelompok siswa SMA Negeri 6 Yogyakarta

\section{Metode}

Pendekatan penelitian ini adalah kualitatif. Jenis metode penelitian kualitatif yang digunakan adalah etnografi. Etnografi merupakan suatu proses dan hasil dari sebuah penelitian yang melibatkan pengamatan yang cukup panjang terhadap suatu kelompok (Darmadi, 2014, p. 290; Creswell, 2015). Penelitian etnografi dapat dilakukan di dalam lingkungan sekolah maupun kelompok sekolah antarperseorangan yang lebih kecil (Hammersley, 1994). Selama pengamatan tersebut, peneliti terlibat dalam keseharian hidup dan mewawancarai subjek penelitian sebagai anggota kelompok sehingga peneliti dapat mempelajari makna dari setiap perilaku, bahasa, dan interaksi dalam kelompok belajar di sekolah.

Penelitian dilakukan di SMA Negeri 6 Yogyakarta dan tempat-tempat yang mendukung terselenggaranya proses belajar kelompok para siswa. Waktu penelitian terlaksana selama 4 bulan, mulai dari per- siapan, perizinan, sampai peneliti mengambil data. Khusus pengambilan data memakan waktu selama 3 bulan, dari awal Maret sampai akhir Mei tahun 2016.

Subjek penelitian ini merupakan informan kunci dan informan. Informan kunci dipilih dengan menggunakan teknik pertimbangan secara purposif, yaitu memilih tokoh-tokoh sekolah yang mengetahui dan menyelenggarakan belajar kelompok di kelas. Informan kunci yang didapatkan adalah wakil kepala sekolah bidang humas, bidang kesiswaan, bidang kurikulum, dan guru. Selanjutnya, informan dipilih secara purposif atas penunjukkan informan kunci dengan menggunakan pertimbangan yang sama seperti ketika memilih informan kunci. Mereka adalah siswa-siswi yang menjalankan aktivitas belajar kelompok. Jumlah informan ditentukan secara snowball, dalam arti wawancara terhadap informan dihentikan apabila data yang diperoleh dipandang sudah memadai, dalam arti sesuai dengan tujuan penelitian. Terdapat 23 informan yang berada di dua kelas.

Peneliti melakukan studi pustaka dan studi lapangan untuk menentukan fokus penelitian. Pada Desember 2015, peneliti memulai melakukan pra survei untuk menemukan kemungkinan-kemungkinan masalah dari praktik belajar kelompok di kelas. Peneliti mewawancarai wakil kepala sekolah urusan humas, kurikulum, dan kesiswaan untuk mendapatkan informasi seputar sejarah, kurikulum, adat kebiasaan warga sekolah, maupun kegiatan kesiswaan. Bulan Februari hingga Mei 2016, peneliti berpartisipasi dalam pembelajaran kelompok di kelas. Setidaknya setiap empat hari, peneliti terlibat dan mengamati lingkungan sekolah baik saat jam pelajaran maupun jam istirahat. Para siswa yang peneliti teliti kebanyakan adalah perempuan karena perbandingan perempuan dengan laki-laki di lokasi adalah 4:1. Peneliti berusaha membangun interaksi dengan para siswa selayaknya teman agar mereka bisa terbuka dalam mengungkapkan persepsi ataupun pemaknaan sebagai data yang peneliti butuhkan. 
Selain melakukan wawancara yang formal, peneliti berusaha menghindari distorsi informasi dengan melakukan perbincangan pada saat siswa menjalankan kegiatan sehari-hari sehingga siswa dibuat sedapat mungkin tidak menyadari apabila dirinya sedang diwawancarai. Setelah peneliti mengamati subjek maupun objek penelitian, sesegera mungkin peneliti membuat catatan lapangan. Catatan lapangan yang dibuat setiap saat menjadi bahan analisis penelitian sehingga peneliti dapat menentukan data apalagi yang harus dicari ataupun data apalagi yang harus diperiksa keabsahannya. Setelah data dirasa jenuh atas penggalian informasi dan pengamatan terlibat, peneliti menghentikan penelitian.

Data diperoleh bersumber dari instrumen penelitian yang dikumpulkan dengan teknik observasi terlibat/berpartisipasi, wawancara mendalam, dan dokumentasi. Data penelitian diambil berdasarkan instrumen pengumpulan data, yang terdiri dari lembar observasi kelas, lembar observasi kelompok, panduan wawancara informan kunci (wakil kepala sekolah dan guru), panduan wawancara informan (siswa), dan panduan dokumentasi pendukung aktivitas belajar kelompok. Data-data yang dikumpulkan seperti persepsi subjek dan perilaku belajar kelompok siswa.

Analisis data dalam penelitian ini bersifat induktif, yaitu analisis yang bermula dari data yang diperoleh, selanjutnya dikembangkan menjadi asumsi/gagasan (Bogdan \& Taylor, 1992; Creswell, 2015). Asumsi/gagasan tersebut selanjutnya dicarikan data kembali secara berulang-ulang sehingga kemudian dapat disimpulkan apakah hipotesis tersebut dapat menjadi tesis/teori yang sifatnya substantif pada penelitian yang tunggal (single social situation) di SMA N 6 Yogyakarta.

Analisis data dalam penelitian ini berlangsung saat sebelum di lapangan, saat pengumpulan data berlangsung, dan setelah selesai pengumpulan data. Analisis sebelum peneliti memasuki lapangan, dilakukan terhadap data hasil studi pendahuluan yang digunakan untuk menentukan fokus penelitian yang sifatnya masih dapat berubah. Selama dan setelah penelitian berlangsung, analisis data mengacu pada model Miles dan Huberman yang dikutip oleh Sugiyono (2011). Analisis data tersebut terdiri dari reduksi data, penyajian data, kemudian penarikan kesimpulan. Ketiga tahapan analisis tersebut diuraikan menjadi beberapa strategi umum berdasarkan Creswell (2015, p.253) yang antara lain, (a) menulis catatan pinggir pada catatan lapangan; (b) menulis kalimat reflektif pada catatan; (c) membuat lembar rangkuman tentang catatan lapangan; (d) membuat metafora; (e) menulis kode, memo; (f) mencatat pola dan tema; (g) menghitung frekuensi dari kode; (h) mencatat hubungan di antara variabel, membentuk rantai-bukti logis; serta (i) membuat kontras dan perbandingan.

Peneliti dengan tekun mengkode catatan-catatan lapangan menggunakan komputer serta memeriksa ulang kode-kode yang membentuk tema. Tema-tema yang muncul kemudian diperiksa dari berbagai strategi keabsahan data seperti triangulasi, meningkatkan ketekunan peneliti, mengklarifikasi bias, membahas bukti kontradiktif, memperpanjang waktu penelitian, maupun mengajak dosen pembimbing serta rekan sejawat untuk berdiskusi dan memeriksa temuan-temuan. Kegiatan-kegiatan tersebut menjadi satu kesatuan dalam kegiatan analisis data yang dilakukan dalam penelitian etnografi. Analisis tersebut menghasilkan tesis-tesis yang berkaitan dengan ketahanan maupun ketidaktahanan belajar kelompok.

\section{Hasil dan Pembahasan}

Hasil

\section{SMA Negeri 6 Yogyakarta dan Siswanya}

Setiap sekolah memiliki ciri yang cukup berbeda satu dengan yang lainnya, terutama jika membandingkan sekolah negeri dengan swasta. Namun demikian, dalam hal kurikulum dan pendekatan pembelajaran tiap sekolah negeri memiliki banyak kesamaan. Sekolah negeri, terutama 
jenjang menengah atas, menyelenggarakan berbagai pembelajaran berbasis kelompok, baik di dalam maupun di luar kelas. Hampir di setiap proses mencapai kompetensi pembelajaran, metode pembelajaran yang diterapkan adalah belajar kelompok, seperti diskusi, berbasis masalah, berbasis proyek, dan metode-metode yang membuat siswa menjadi lebih aktif. Sebab, sekolah memiliki kewajiban untuk menghasilkan siswa yang mampu bekerja sama, aktif, terbuka, mandiri dan bertanggung jawab.

Pertimbangan dalam memilih lokasi penelitian ini adalah terletak pada kenyataan bahwa tiap sekolah negeri memiliki desain pembelajaran yang tidak berbeda jauh satu dengan yang lainnya. Sekolah menengah atas dipilih karena merupakan sekolah yang memiliki siswa dengan rentang usia 14-18 tahun. Siswa SMA tergolong memiliki pergaulan yang lebih luas serta pengalaman berkelompok yang diyakini lebih lama dibandingkan jenjang di bawahnya. Pertimbangan selanjutnya adalah pada keunikan suatu institusi sekolah yang memiliki sejarah aktivitas kelompok dari yang negatif hingga positif. Sekolah yang mampu mengubah reputasi yang semula buruk menjadi baik menjadi pertimbangan untuk diselidiki lebih dalam meskipun fokus penelitian terletak pada belajar kelompok yang sifatnya untuk mencapai kompetensi-kompetensi bidang studi.

Penelitian ini berlokasi di SMA N 6 Yogyakarta, Jalan Cornelis Simanjuntak 2, Kelurahan Terban, Kecamatan Gondokusuman. Sekolah ini didirikan pada 17 September 1949 dengan nama awal adalah SMA Yuridis Ekonomi. Di awal masa berdirinya, SMA N 6 Yogyakarta dikenal mempunyai reputasi yang baik. Reputasi sekolah mulai terguncang mulai tahun 1995 dan seterusnya karena dianggap sebagai era bermunculannya aktivitas kelompok seperti tawuran antar pelajar. SMA N 6 Yogyakarta bertahun-tahun mendapatkan label sekolah biang keonaran karena ulah siswa-siswanya yang sulit diatur. Anggita (2014) mengungkapkan hasil penelitiannya bahwa aksi keberutalan siswa yang cukup ekstrem terjadi pada rentang waktu 20032007 serta salah satu kasus di penghujung tahun 2009 menyebabkan tewasnya salah seorang alumni SMA N 6 dan seorang lainnya sempat koma karena mengalami hantaman serta remuk di bagian wajah. Namun demikian, sekolah terus membenahi reputasi melalui peran manajemen sekolah yang mendeklarasikan diri sebagai " $R e$ search School of Jogja" sehingga kegiatan belajar dan pembelajaran diarahkan pada kegiatan penelitian.

Kebanyakan siswa di sekolah tersebut merupakan orang asli Yogyakarta yang berdomisili di daerah Kota Yogyakarta dan perbatasan Kota Yogyakarta dengan Sleman. Ada juga siswa yang merupakan warga pendatang seperti, Jakarta maupun Sumatera Selatan yang disebabkan orang tuanya bekerja di Yogyakarta. Siswa di kedua kelas tergolong masyarakat urban karena bersekolah di pusat Ibukota DIY akan tetapi mereka tetap terlihat menjunjung tinggi nilai budaya Yogyakarta.

Para siswa memiliki komunitas di dunia nyata dan dunia maya yang mereka merasa harus aktif bersosialisasi. Sering peneliti menemukan bahwa siswa sedang asyik membuka media sosial internet saat pembelajaran kelompok berlangsung. Saat mereka berkumpul bersama di jam istirahat pun mereka tidak pernah lepas untuk membuka media sosial internet melalui gadget masing-masing. Hal ini menandakan bahwa berkelompok pun harus mengikuti perkembangan teknologi meskipun banyak tantangan yang bisa menjadi gangguan.

\section{Tiada Hari Tanpa Belajar Kelompok}

Selama peneliti terlibat di kelas, setiap pertemuan pembelajaran, kecuali ulangan harian, diisi dengan menggunakan strategi belajar kelompok. Setidaknya, dua orang siswa adalah ukuran terkecil kelompok yang dibentuk untuk saling berbagi ide dan gagasan. Para siswa bertugas untuk mengidentifikasi, menganalisis, membuat, dan mendiskusikan suatu topik maupun tugas pembelajaran. Mereka dilatih 
untuk membuat sesuatu sesuai kemampuan kognitif, afektif, maupun psikomotor yang kemudian membagikannya satu sama lain untuk mendapatkan umpan balik dan konfirmasi kebenaran.

\section{Siswa Memaknai Belajar Kelompok}

Secara keseluruhan, persepsi siswa perihal pengertian belajar kelompok dapat dirangkum ke dalam Tabel 1.

Tabel 1. Persepsi Siswa Perihal Pengertian Belajar Kelompok

\begin{tabular}{cl}
\hline No & Pengertian Belajar Kelompok \\
\hline 1 & Belajar (mendalami materi) bersama-sama; \\
2 & Mengerjakan tugas bersama-sama; \\
3 & Bertanya dan mengajari; \\
4 & Saling kerja sama (team work); \\
5 & Pembagian tugas-tugas; \\
6 & Tanggung jawab masing-masing anggota \\
& kelompok; \\
7 & Berdiskusi untuk menyelesaikan masalah; \\
8 & Ada interaksi dan komunikasi antar-anggota. \\
\hline
\end{tabular}

Data yang terkumpul mengenai persepsi siswa terhadap belajar kelompok dapat peneliti kerucutkan ke dalam dua hal. Pertama, belajar kelompok berarti keinginan siswa untuk aktif terlibat di dalam proses pembelajaran kelompok. Kedua, belajar kelompok berarti belajar mengasah keterampilan berinteraksi dengan orang lain (interpersonal skills).

Siswa juga memaknai apa yang menjadi manfaat belajar kelompok ke dalam pengertian belajar kelompok yang mereka pahami. Manfaat belajar kelompok yang didapatkan oleh siswa dapat peneliti kerucutkan menjadi beberapa hal. Pertama, belajar kelompok bermanfaat untuk mencapai keefektifan pembelajaran dengan indikasi pemahaman siswa terhadap suatu materi menjadi meningkat. Kedua, belajar kelompok bermanfaat untuk memudahkan siswa belajar dengan cepat bersama teman sebayanya. Ketiga, belajar kelompok bermanfaat untuk melatih keterampilan sosial kooperatif (cooperative social skills).

Manfaat belajar kelompok menjadi alasan siswa termotivasi untuk melakukan belajar kelompok. Peneliti kemudian menggali apa motivasi siswa tergerak untuk belajar kelompok. Belajar kelompok dianggap menyenangkan atau tidak tergantung pada motivasi siswa melakukannya. Ketika siswa mengungkapkan perasaannya tentang motivasi melakukan belajar kelompok, peneliti mendapatkan kenyataan bahwa tidak semua siswa menyukai belajar kelompok. Namun demikian, sebagian besar siswa senang belajar kelompok dengan berbagai macam motivasi. Berikut ini adalah variasi motivasi para siswa terhadap belajar kelompok.

Tabel 2. Persepsi Siswa Perihal Manfaat Belajar Kelompok

\begin{tabular}{cl}
\hline No & Manfaat Belajar Kelompok \\
\hline 1 & Tugas kelompok menjadi lebih cepat selesai; \\
2 & Menjadi lebih paham materi pelajaran; \\
3 & Kemampuan komunikasi dapat terasah; \\
4 & Hubungan interpersonal menjadi lebih dekat; \\
5 & Dapat mengetahui kepintaran teman sehingga \\
& dapat dijadikan referensi bertanya. \\
\hline
\end{tabular}

Tabel 3. Motivasi Siswa Belajar Kelompok

\begin{tabular}{l}
\hline Kurang Menyukai Belajar Kelompok: \\
\hline 1. Merasa lebih nyaman ketika belajar sendiri. \\
2. Ingin berusaha mengerjakan sesuai \\
kemampuannya terlebih dahulu. \\
3. Merasa lebih cepat mempelajari suatu hal secara \\
sendiri. \\
4. Merasakan bahwa belajar sendiri dapat lebih \\
mudah fokus dan dirasa lebih tenang \\
dibandingkan belajar kelompok. \\
5. Tidak ingin membebani dan terbebani orang lain \\
dalam tugasnya. \\
6. Tidak bisa bekerja sama dengan mereka yang \\
tidak bertanggung jawab mengerjakan tugas. \\
7. Tugas yang dikerjakan oleh temannya tidak \\
sesuai harapan atau ekspektasinya. \\
\hline Menyukai Belajar Kelompok: \\
1. Ingin menjadi bagian dari aktivitas berbagi ilmu. \\
2. Saat menemukan materi pelajaran yang sulit \\
dipahami. \\
3. Menyadari ada manfaat yang diperoleh. Seperti \\
menjadi lebih paham materi pelajaran dan tugas \\
kelompok menjadi lebih cepat selesai. Ada juga \\
yang mendapatkan manfaat belajar kelompok \\
berupa kesempatan bermain dengan teman- \\
temannya. \\
Mengerjakan tugas kelompok bersama-sama \\
dengan teman yang sudah akrab. \\
5. Ingin meningkatkan kualitas hubungan \\
interpersonal
\end{tabular}


Motivasi siswa melakukan belajar kelompok bervariasi karena orientasi yang ingin dicapai berbeda. Orientasi pertama adalah orientasi pada akademik (academic oriented). Para siswa cenderung fokus pada peningkatan pemahaman ataupun pencapaian terhadap pelajaran daripada berinteraksi dengan sesama teman. Orientasi kedua adalah orientasi pada kelompok (cooperatively oriented). Ketika siswa berorientasi pada kelompok, siswa cenderung suka menghargai sesama temannya, tidak masalah pada level mana kecerdasan mereka.

Siswa yang termotivasi belajar kelompok karena sebagian besar orientasi pada akademik (academic oriented) terlihat lebih senang mengerjakan tugas secara sendiri dan merasa kurang menyukai belajar kelompok. Belajar sendiri dapat membuat siswa memahami pelajaran ataupun menyelesaikan tugas tanpa perlu terganggu oleh siswa lainnya. Mereka beranggapan bahwa tidak perlu khawatir menyinggung perasaan teman ataupun melakukan kesalahan pada hubungan sosial. Mereka tidak perlu menggantungkan diri kepada temantemannya karena tugas dari guru bisa diselesaikan sendiri.

Mereka yang lebih menyukai belajar sendiri bukan berarti tidak melakukan belajar kelompok karena mereka juga masih dikondisikan oleh guru untuk saling berinteraksi. Apalagi ketika bisa satu kelompok dengan teman yang disukai, siswa akan merasa senang belajar kelompok. Hanya saja, kesadaran atas manfaat belajar kelompok di kelompok yang heterogen masih terbatas. Anggapan dan perasaan seperti berasal dari siswa yang tergolong menonjol secara akademik.

Selanjutnya adalah siswa yang termotivasi belajar kelompok karena sebagian besar orientasi pada kelompok (cooperatively oriented). Siswa yang seperti ini memiliki solidaritas yang tinggi terhadap sesama teman. "Masalah kamu adalah masalah aku dan masalah aku adalah masalah kamu". Siswa akan berusaha membangun integritas diri di hadapan teman-temannya. Mereka akan membangun dan merawat hubungan interpersonal menjadi lebih baik. Siswa yang seperti ini menyukai berkelompok dengan siapa saja tetapi ketika telah menemukan kelompok yang mapan maka akan dijaga kemapanan itu. Hanya saja, orientasi pada tugas atau materi pelajaran menjadi dikesampingkan sehingga tidak jarang mereka tidak optimal dalam kualitas tugas atau materi pelajaran yang dikerjakan.

\section{Pembentukan Kelompok}

Belajar kelompok dapat terselenggara dari inisiatif siswa sendiri. Belajar kelompok atas inisiatif sendiri biasanya terbentuk atas kesadaran siswa yang memiliki kedekatan emosional. Semula, mereka merupakan sekumpulan orang yang sering berinteraksi tetapi menjadi kelompok belajar ketika satu sama lain memiliki kesamaan motif, misalnya sama-sama ingin belajar. Tiap anggota kelompok menjadikan berkelompok sebagai modal sosial yang dilandasi perasaan nyaman satu sama lainnya. Perasaan merasa nyaman inilah yang oleh ahli Sosiologi sebagai salah satu pembeda kelompok dengan kumpulan (Schaefer, 2012, p.13).

Belajar kelompok dapat terselenggara juga karena diarahkan dan dikondisikan oleh guru. Kenyataan ini lebih mendominasi daripada belajar kelompok atas inisiatif siswa sendiri. Guru memiliki peran sentral dalam persiapan pembelajaran kelompok. Guru biasanya memberikan tugas yang harus dikerjakan secara berkelompok kepada para siswa. Tiap tugas perlu diselesaikan dengan variasi ukuran kelompok yang berbeda-beda dan tergantung pada jenis-jenis tugas.

Berdasarkan pengamatan peneliti, setidaknya ada tiga cara menentukan anggota kelompok dalam pembelajaran kelompok di kelas, yaitu dengan cara (1) berhitung, (2) siswa memilih sendiri, atau (3) guru yang menentukan. Sebelum menentukan cara menentukan anggota kelompok, guru terlebih dahulu menjelaskan tugas dan tujuan pembelajaran kelompok sehingga dapat tergambar ukuran kelompok yang seharusnya terbentuk. 
Para siswa cenderung menyukai pembentukan kelompok dengan memilih sendiri karena mereka dapat memilih teman berdasarkan motif yang diinginkan. Alasan memilih teman ini diakui siswa sebagai jaminan atas keberlangsungan kelompok belajar mereka. Berikut adalah variasi alasan siswa memilih teman untuk diajak belajar kelompok:

Tabel 4. Variasi Alasan Memilih Teman Sekelompok

\begin{tabular}{cl}
\hline No & Kriteria \\
\hline 1 & Rajin mengerjakan tugas; \\
2 & Pintar; \\
3 & Sudah mengenal dekat/akrab; \\
4 & Mau bekerja sama; \\
5 & Bertanggung jawab; \\
6 & Enak diajak diskusi; \\
7 & Komunikasi bagus; \\
8 & Mudah diajak berkumpul; \\
9 & Terbuka, fleksibel, dan santai. \\
\hline
\end{tabular}

Cara-cara menentukan anggota kelompok memiliki implikasi pada komposisi anggota kelompok. Komposisi anggota kelompok dapat terbentuk seperti komposisi beraneka-ragam (heterogeneous), seragam (homogeneous), dan berdasarkan tujuan tertentu (purposive oriented). Guru mengakui bahwa komposisi acak merupakan ruang heterogenitas yang dihasilkan tanpa memilih-milih teman sehingga setiap anak dianggap utama dan diakui perannya. Komposisi heterogen adalah komposisi yang paling didukung oleh guru meskipun sebagian besar siswi lebih menyukai komposisi homogen. Pada kenyataannya, siswa cenderung menyukai kondisi yang semua anggotanya mau bekerja sama dan rajin (homogen dalam kinerja) sedangkan guru cenderung menempatkan siswa yang rajin dengan yang kurang rajin dalam satu kelompok.

Komposisi kelompok berdasarkan gender merupakan persoalan yang sensitif dalam ruang negosiasi siswa saat belajar kelompok. Sebagian besar siswa mempertunjukkan perilaku saling berbagi beban menjadi kesatuan kolektif. Kelompok belajar yang berisi semua perempuan dimaknai oleh anggota yang terlibat di dalamnya sebagai kesatuan kolektif yang prestatif dan di luar komposisi tersebut, mereka anggap akan sulit berprestasi. Namun demikian, kelompok belajar yang berisi semua laki-laki maupun campuran dimaknai oleh siswa laki-laki sebagai kesatuan yang berpeluang sama untuk berprestasi.

\section{Peran Individu dalam Kelompok}

Guru berperan dalam penentuan peran siswa di tiap kelompok tersebut. Biasanya, guru langsung menunjuk individu siswa untuk menjadi ketua kelompok dan biasanya guru membebaskan siswa untuk berinteraksi secara alamiah, tanpa ada intervensi yang banyak dari guru. Ada ketua kelompok yang mempraktikkan pengaturan peran di dalam kelompok maupun mengontrol jalannya diskusi dalam kelompok. Namun, ada pula siswa yang tidak menyadari bahwa siswa tersebut adalah ketua sehingga melemparkan tanggung jawab kepada semua anggota kelompok. Anggota kelompok pun menganggap tidak penting adanya ketua, apalagi kelompok yang berukuran tiga sampai lima orang. Mereka mementingkan bahwa semua orang memiliki tanggung jawab yang sama dan harus bekerja optimal.

Beberapa kelompok bekerja secara kooperatif dan sebagian besar kelompok tidak selalu bekerja bersama. Kelompok yang terlihat bekerja bersama berperilaku seperti mendiskusikan ide-ide, menemukan solusi, dan berbagi jawaban. Kadangkadang, satu siswa muncul sebagai pemimpin, memonitor kelompok, dan membagibagi tugas. Mereka satu sama lain saling bertatap muka menyimak pendapat masingmasing. Fenomena ini menunjukkan dalam kelompok terjadi pembagian peran yang kooperatif.

Sebagian besar kelompok tidak selalu bekerja bersama. Walaupun posisi duduk mereka sudah representatif, mereka terlihat bekerja sendiri-sendiri. Kelompok semula terdengar sibuk membagi-bagi tugas dan selebihnya terlihat hening pada sisasisa waktu pembelajaran. Keheningan ini 
disebabkan oleh dua hal. Penyebab pertama adalah setiap siswa mendapatkan tugas untuk memecahkan masalah yang berbedabeda dan dilakukan secara sendiri sehingga pertukaran pendapat dari yang lain tidak terjadi. Fenomena ini menunjukkan bahwa peran-peran kooperatif sedikit bergeser pada peran yang individualistis meskipun masih dalam satu kelompok.

Penyebab kedua adalah adanya gangguan yang menyita perhatian anggota dalam kelompok. Konsentrasi siswa menjadi terpecah karena membuka media sosial di smart phone masing-masing. Mereka lebih tertarik pada konten yang disuguhkan di internet seperti, media bincang-bincang LINE, Facebook, dan Twitter. Akibatnya, sebagian siswa mengikuti belajar kelompok secara setengah hati. Hanya sedikit siswa yang sadar yang kemudian mengerjakan tugas kelompok tersebut meskipun harus menanggung lebih banyak beban karena konsentrasi anggota kelompok yang lain terpecah.

\section{Aktivitas dan Suasana Belajar Kelompok}

Pembelajaran kelompok dapat terjadi tidak terlepas dari peran penting guru. Beberapa langkah yang dilakukan guru meliputi: menyajikan sedikit materi sebagai wawasan awal kepada siswa, memberi tahu tujuan pembelajaran yang melibatkan kelompok, menentukan ukuran kelompok, membantu pembentukan kelompok, mengawasi proses belajar kelompok, menjawab kebingungan siswa, menegur siswa yang melenceng dari pembelajaran, memberikan koreksi pemahaman siswa, dan memberikan penilaian atas pencapaian siswa dalam kelompok.

Selama belajar kelompok, siswa yang kelompoknya terlihat kompak menunjukkan sikap saling menolong satu sama lain. Misalnya, siswa membantu menjawab soal di buku latihan ataupun menyimak dan saling mendukung melalui komunikasi yang aktif. Mereka juga terlihat membagi-bagi tugas (seperti tugas membuat karya tulis dan makalah) menjadi bagian- bagian yang bisa dikerjakan oleh perorangan. Kemudian tugas perorangan tersebut disatukan sesuai waktu yang disepakati.

Ketika ada yang tidak menepati janji atau tidak bertanggung jawab pada tugas perorangan, ada anggota lainnya yang mengambil peran untuk menyelesaikan tugas tersebut. Sementara yang lain menggerutu di belakang, anggota yang tidak bertanggung jawab ini merasa terbantu dengan adanya satu orang yang mengerjakan tugasnya. Tugas kelompok menjadi selesai dan terlihat kompak karena satu sama lain melengkapi. Namun demikian, ada dampak negatif yang berkaitan dengan hubungan interpersonal. Di satu sisi, integritas siswa yang tidak bertanggung jawab menjadi lemah sehingga akan cenderung dijauhi temannya dan di sisi berbeda, siswa yang lain memendam perasaan tidak enak. Saat pembelajaran kelompok selesai, berarti selesai pula hubungan kerja sama mereka, tanpa ada evaluasi pada internal kelompok.

Sebagian besar kelompok yang lain, terlihat santai dalam aktivitas kelompok. Santai dalam artian mereka banyak berbincang sesuatu yang di luar topik belajar kelompok. Mereka bercanda satu sama lainnya, lebih sering membuka smart phone, dan menunda-nunda penyelesaian tugas. Mereka seolah sibuk dengan kesukaannya saat itu sehingga terlihat tidak sedang belajar kelompok. Walaupun posisi duduk sudah mendukung, mereka sedikit sekali membahas bagaimana mencapai tujuan pembelajaran kelompok dan menyelesaikan tugas. Ketika guru mendekati, konsentrasi mereka kembali pada kelompok, biasanya mereka akan bersahut-sahutan dalam menyampaikan ide. Suasana belajar menjadi terasa tidak terarah dengan baik (sporadis).

Sebagian besar siswa lebih nyaman jika mengerjakan tugas kelompok di kelas. Mereka memanfaatkan jam istirahat maupun jam pelajaran yang kosong untuk membagi-bagi tugas pada tiap individu. Tugastugas yang telah dibagi menjadi tanggung jawab individu untuk mencari dan menyelesaikannya selama tenggang waktu yang 
disepakati bersama. Pembagian tugas diyakini beberapa siswa dapat mempercepat tugas selesai. Setelah tiap individu menyelesaikan tanggung jawab-nya, hasil pekerjaan tiap individu disatu-kan secara bersamasama ataupun oleh sa-lah seorang di antara mereka. Pada masa-masa saat ini, biasanya akan muncul konflik.

Ketika tugas yang dikumpulkan individu siswa tidak selesai dan tidak sesuai harapan, sementara waktu pengumpulan sudah di depan mata, suasana kelompok menjadi kisruh. Akibatnya, kegiatan-kegiatan seperti diskusi dan mengasah keterampilan sosial kooperatif, terjadi sangat singkat. Kelompok menjadi sekadar beban untuk menyelesaikan tugas dari guru.

Tugas kelompok yang telah selesai dikerjakan, kemudian dikumpulkan kepada guru dan siswa melakukan presentasi di muka kelas. Saat presentasi kelompok berlangsung, idealnya adalah semua siswa yang tidak sedang presentasi harus menyaksikan dan menyimak kelompok penyaji (presenter). Akan tetapi terjadi fenomena bahwa sebagian besar siswa sibuk dengan pekerjaannya masing-masing. Ada yang membuka laptop, memainkan smart phone, ataupun mengerjakan tugas lain yang tidak berkaitan dengan pelajaran saat itu. Peneliti melihat bahwa kelompok penyaji tidak mampu mengambil perhatian teman-temannya untuk fokus pada mereka. Dengan kata lain, penyaji maupun presentasinya tidak cukup menarik untuk disimak.

Aktivitas belajar kelompok yang terjadi di kelas tidak terlepas dari berbagai kemunculan konflik. Konflik biasanya akan muncul ketika nampak ketidakharmonisan antar individu. Peneliti mereduksi data temuan mengenai konflik-konflik yang terjadi selama siswa belajar kelompok ke dalam Tabel 5.

Penyebab konflik merupakan gangguang dalam belajar kelompok sehingga belajar kelompok dapat menjadi tidak tahan. Gangguan yang sering terjadi pada kelompok belajar di sekolah adalah salah pengertian dan salah persepsi, pembagian tugas yang tidak seimbang dan merugikan, serta konsentrasi terpecah. Penyebab konflik tersebut dapat mengakibatkan tujuan kelompok tidak dapat tercapai. Namun kelompok belajar yang tahan berusaha mengatasi konflik sesuai dengan pengalaman berinteraksi dengan orang lain.

Tabel 5. Konflik Kelompok dan Reaksi Penyelesaiannya

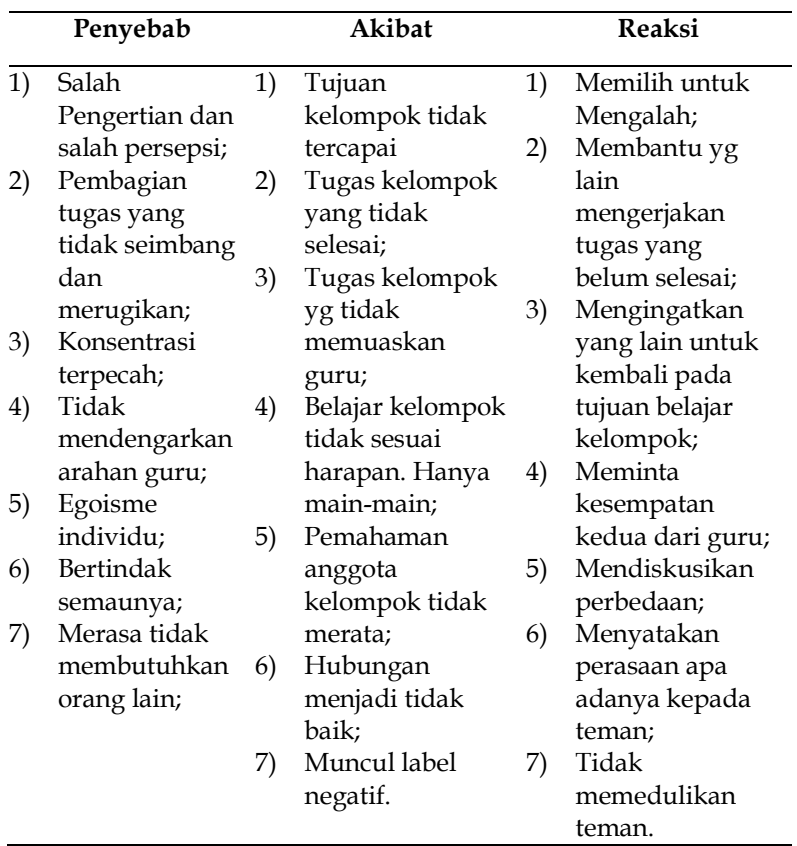

\section{Pembahasan}

\section{Kontribusi Ketahanan Belajar Kelompok}

Sebagaimana pula kelompok yang terbentuk karena tujuan-tujuan pembelajaran di kelas, ada kelompok yang tahan dan ada kelompok yang tidak tahan. Berdasarkan perilaku-perilaku siswa di dalam tiap kelompok, menunjukkan bahwa ada kontribusi yang membuat sebuah kelompok dapat mendekati tahan. Meskipun sebagian besar kelompok-kelompok di kelas yang terbentuk karena strategi belajar kelompok hanya sekadar belajar kelompok yang mengerjakan tugas sehingga mengaktifkan siswa yang satu dan mempasifkan siswa yang lain.

Perilaku siswa yang terjadi dalam menyikapi belajar kelompok merupakan cerminan budaya yang melekat dalam diri dan lingkungan siswa. Siswa belajar dari 
orang tua, guru, dan teman dalam menyikapi kebutuhan berkelompok. Orang-orang di sekitar siswa membawa pengaruh yang mampu mengarahkan persepsinya sebagai individu yang membutuhkan kebersamaan dalam belajar ataupun terbiasa belajar tanpa perlu mementingkan orang lain.

Namun selalu ada sekelompok siswa yang percaya bahwa belajar haruslah bersama meskipun harus mengesampingkan egoisme pribadi yang mampu maju ke depan sendiri dengan lebih cepat. Sekelompok siswa tersebut meyakini bahwa impresi dari belajar kelompok dapat membuat pekerjaan menjadi lebih cepat selesai, berbeda dari pandangan sinis kaum yang mengutamakan pembelajaran individu yang mengakselerasi. Bahwa belajar tidak hanya menambah pengetahuan tetapi juga keterampilan sosial, menjadi persepsi siswa mengenai manfaat belajar kelompok. Persepsi inilah yang membuat sekelompok siswa menjalani belajar kelompok dengan antusias dan berusaha mengerti satu sama lain.

Perilaku-perilaku maupun dinamika kebudayaan yang terjadi di kelas dapat menjadi kompak dan kooperatif direpresentasikan sebagai kelompok yang memiliki ketahanan yang tahan, kuat, dan bagus dalam mengawali dan mengakhiri kelompok. Ketahanan belajar kelompok merupakan esensi dari budaya yang tercipta dari kelompok siswa yang mampu bertahan dan berprestasi bersama di dalam kelompok.

Makna di balik ketahanan belajar kelompok yang terjadi di SMA N 6 Yogyakarta adalah kemampuan suatu kelompok belajar dapat tahan dalam kondisi apapun dalam melaksanakan aktivitas belajar kooperatif sehingga bertambah pengetahuan, keterampilan, dan sikap anggotanya. Ada tiga bagian yang melingkupi makna dari ketahanan belajar kelompok yaitu, (a) kemampuan kelompok belajar yang tahan dalam kondisi apapun; (b) melasanakan aktivitas belajar kooperatif; (c) bertambah pengetahuan, keterampilan, dan sikap anggotanya.

Ketahanan belajar kelompok dapat tercipta karena adanya kontribusi yang me- wujudkannya. Kontribusi tersebut dapat berupa faktor ataupun hal-hal yang menjadi sebab tercapainya ketahanan belajar kelompok. Kontribusi kelompok dapat menjadi tahan: (a) persepsi terhadap esensi belajar kelompok yang kooperatif dan tidak individualistik. Faktor budaya komunal mendukung ini; (b) rasa percaya di antara anggota yang tercipta dari usaha mengenal/menjadi dekat antar anggota; (c) saling bergantung, saling mendukung, saling bekerja sama, saling menolong, dan saling berbagi beban di dalam kelompok; serta (d) tanggung jawab tiap anggota yang diperankan dengan tepat dan proporsional. Berikut pembahasan mengenai kontribusi ketahanan belajar kelompok.

Apa yang Johnson, Johnson \& Holubec (2010, p.60) simpulkan dari penelitiannya mengembangkan belajar kelompok melalui tipe Learning Together hampir merepresentasikan penemuan-penemuan dalam tesis ini. Johnson, Johnson, \& Holubec menyimpulkan bahwa kelompok belajar untuk menjadi kooperatif haruslah memiliki interdependensi positif yang jelas, para anggotanya harus saling mendorong pembelajaran dan keberhasilan satu sama lain dalam kegiatan tatap muka, mendukung satu sama lain secara personal, bertanggung jawab secara individual untuk melakukan porsi kerja yang wajar, dan memproses seberapa efektif mereka telah bekerja sama.

Teori Lewin dapat direfleksikan pada komponen ketercapaian tujuan belajar. Lewin yang menemukan teori interdependensi sosial (Social Interdependence Theory) bahwa interdependensi sosial dapat terjadi ketika tiap individu bersama-sama menanggung sebuah tujuan bersama, dan tiap hasil individu distimulasi (dibangkitkan) dari langkah-langkah tiap individu yang ada di dalam kelompok. Lewin mengklaim bahwa tiap orang dapat bergabung dalam satu kelompok dengan watak dan ide yang berbeda-beda, tetapi dapat bekerja sama untuk mencapai tujuan bersama sepanjang mereka memahami dan setuju dengan tujuan bersama atau target akhir. Asalkan tujuan bersama dipahami dengan baik 
(Lewin, 1948). Kelompok yang memiliki interdependensi positif secara signifikan dapat menghasilkan pencapaian yang baik (Nam, 2008).

Sepanjang setiap individu dalam kelompok memiliki keinginan untuk berinteraksi secara intens maka rasa percaya akan tumbuh. Allport dalam (Slavin, 2009, p.101) melalui teori kontak menyatakan bahwa terjadinya kontak sangat penting sehingga mampu membangun hubungan pada individu yang berbeda ras. Apalagi antar-individu yang memiliki kesamaan ras, tentu peluang tumbuhnya rasa saling percaya menjadi terbuka lebar.

Rasa saling percaya akan tumbuh di dalam kelompok ketika kelompok masuk ke dalam fase pembentukan norma (norming) dalam kelompok (Tuckman et.al. dalam Munir, 2001, p. 13). Siswa semula tidak saling mengenal ketika bergabung ke dalam kelompok. Mereka membutuhkan waktu untuk menyamakan persepsi dan norma demi mencapai tujuan bersama. Penyamaan persepsi ini sifatnya terus menerus sepanjang interaksi dalam peristiwa-peristiwa kelompok. Maka rerata kelompok yang dapat menumbuhkan rasa saling percaya di antara anggotanya adalah mereka yang sudah saling mengenal. Tidak heran bila para siswa di kelas lebih menyukai memilih sendiri anggota kelompoknya saat penentuan kelompok. Mereka cenderung memilih anggota kelompok yang dekat atau sudah dikenal baik sehingga tidak akan merasa canggung ketika berkomunikasi. Interaksi kelompok yang menumbuhkan rasa percaya sehingga membuat kelompok menjadi tahan, disebut oleh (Johnson et al., 2010; Stahl, 1994) sebagai face-to-face interaction (interaksi promotif tatap-muka).

Setiap anggota dalam kelompok yang tahan menunjukkan perilaku seperti ketergantungan satu sama lain dalam mencapai tujuan, saling mendukung, bertanggung jawab pada dirinya atas tugas-tugas yang diperankan, berdiskusi, berkomunikasi, memecahkan masalah, bahkan bisa mendengarkan pendapat orang lain. Perilaku-perilaku ini menunjukkan bahwa bel- ajar kelompok menjadi kooperatif sehingga kelompok nampak kohesif dan tahan. Saling bergantung satu sama lain mengarahkan siswa pada pengambilan sikap yang mementingkan kepentingan kelompok karena keberhasilan teman merupakan keberhasilan juga bagi dirinya sendiri.

Tiap anggota kelompok mengerti bahwa masing-masing punya tanggung jawab. Saat diskusi kelompok menghasilkan ide yang disepakati untuk dicapai, maka kelompok siswa yang sudah saling mengenal secara dekat tersebut memberikan tanggung jawab sesuai keahlian masing-masing. Mereka percaya satu dengan yang lainnya mampu memberikan upaya yang optimal. Hal ini melahirkan konsekuensi untuk bertanggung jawab kepada tujuan kelompok.

\section{Kontribusi Ketidaktahanan Belajar Kelompok}

Perilaku-perilaku maupun dinamika kebudayaan yang terjadi di kelas dapat menjadi tidak kompak dan cenderung menjadi individualistis direpresentasikan sebagai kelompok yang memiliki ketahanan yang tidak tahan, tidak kuat, dan tidak kompak dalam mengawali dan mengakhiri kelompok. Hal ini dapat disebut sebagai ketidaktahanan kelompok. Ketidaktahanan belajar kelompok merupakan esensi dari budaya yang tercipta dari kelompok siswa yang tidak mampu bertahan dan berprestasi bersama di dalam kelompok.

Makna di balik ketidaktahanan belajar kelompok yang terjadi di SMA N 6 Yogyakarta adalah kemampuan suatu kelompok belajar, tidak tahan dalam melaksanakan aktivitas belajar kooperatif, menimbulkan konflik kelompok yang tidak diselesaikan, dan cenderung individualistik sehingga tujuan belajar kelompok menjadi tidak tercapai. Ada tiga bagian yang melingkupi makna dari ketidaktahanan belajar kelompok yaitu, (a) kemampuan kelompok belajar yang tidak tahan dalam belajar kooperatif; (b) cenderung individualistik; dan (c) tujuan belajar kelompok menjadi tidak tercapai.

Kontribusi ketidaktahanan belajar kelompok meliputi, (a) persepsi terhadap 
esensi belajar kelompok sebagai kompetisi. Orientasi individualistik dan akademik mendominasi; (b) sekadar formalitas karena tuntutan sistem sehingga siswa setengah hati membangun kelompok; (c) saling bersaing tanpa peduli kemajuan bersama misalnya, bersikap menentang, mendominasi, mencari muka; (d) pragmatisme belajar dengan mendompleng tanggung jawab orang lain.

Belajar kelompok yang tidak tahan didominasi dengan persepsi siswa mengenai belajar kelompok sekadar mengerjakan tugas dari guru tanpa memandang penting adanya tujuan pengembangan keterampilan sosial. Motivasi siswa cenderung tidak terlalu menyukai belajar kelompok. Siswa terlihat tidak terlalu membutuhkan belajar kelompok. Hal ini tercermin dari perilaku siswa yang individualistis, sulit memaklumi perbedaan dan menganggap setiap siswa memiliki standar yang sama dengannya. Siswa tersebut akan lebih menyukai belajar sendiri karena tidak perlu menyamakan persepsi dan memahamkan agar siswa lain dalam kelompoknya paham. Siswa juga mengaku trauma belajar kelompok jika dengan anggota kelompok yang tidak bisa diajak kerja sama.

Persepsi siswa yang individualistis ini akan melahirkan tindakan-tindakan hasil dari persepsi yang berupa kompetisi. Hal ini menunjukkan bahwa ada perbedaan tujuan yang dipahami oleh tiap individu. Akibatnya anggota kelompok sering mengalami konflik persepsional.

Belajar kelompok yang tidak tahan, bermula dari pertumbuhan kelompok yang tidak terjadi secara utuh. Upaya-upaya awal untuk membangun komunikasi di antara anggota kelompok terjadi sangat singkat bahkan dianggap tidak penting. Bagi siswa, belajar kelompok adalah perintah dari guru yang harus diselesaikan. Maka tidak heran jika kebanyakan kelompok di kelas, baru memulai mendiskusikan masalah kelompok ketika menjelang batas akhir tugas kelompok dikumpulkan kepada guru. Saat berkumpul bersama, konsentrasi siswa pun mengalami gangguan.
Fenomena ini menunjukkan bahwa belajar kelompok adalah tugas yang harus dibagi-bagi kepada anggota yang terlibat di dalamnya. Perkara siswa mengerjakannya secara individu, tidak menjadi permasalahan karena rajin atau tidak rajinnya siswa, tugas kelompok akan tetap selesai oleh sebagian kecil siswa yang berorientasi pada tugas. Siswa yang berorientasi pada tugas menganggap bahwa kemajuan siswa tergantung pada pribadi masing-masing.

Interaksi yang formalitas dalam pengkondisian belajar kelompok tercipta dari setidaknya dua jenis siswa. Jenis pertama adalah siswa yang senang berkumpul dengan teman-temannya tetapi membahas topik di luar pelajaran sedangkan jenis kedua adalah siswa yang berorientasi pada tugas dan menganggap berkumpul dengan siswa yang suka mengobrol sebagai sia-sia dan tidak produktif. Ketika kedua jenis siswa ini menjadi satu dan tidak menurunkan ego pribadi, maka belajar kelompok menjadi tidak kohesif. Dengan kata lain, mereka tidak siap untuk berdiri bersama dan menanggung beban (Lewin, 1948). Interaksi yang formalitas menjadikan siswa cenderung bersaing demi kepentingan pribadi karena berkelompok tidak menjadi kebutuhan.

Interdependensi negatif (berupa persaingan) akan menghasilkan interaksi yang sifatnya oposisional (menentang) dimana setiap individu saling menjatuhkan dan mematahkan usaha satu sama lain untuk mencapai sesuatu. Seperti, mengunggulkan diri sendiri dapat menafikan kepentingan kelompok. Hal ini berdampak pada kepuasan maupun ketidakpuasan anggota kelompok.

Para siswa yang lemah atau kurang berorientasi pada akademik menjadi bergantung secara personal kepada orang lain. Mereka menjalani aktivitas belajar kelompok menjadi sekadarnya, seperti muncul pandangan karena ada si A, tugas dapat selesai tepat waktu walaupun yang bersangkutan tidak memberikan kontribusi nyata. Pragmatisme belajar ini tercermin dari seringnya siswa mendompleng tang- 
gung jawab orang lain dengan sekadar menitip nama dalam hasil kelompok.

\section{Simpulan}

Fenomena ketahanan belajar kelompok yang terjadi di sekolah dapat dimaknai sebagai kemampuan suatu kelompok belajar dapat tahan dalam kondisi apapun melaksanakan aktivitas belajar kooperatif sehingga bertambah pengetahuan, keterampilan, dan sikap anggotanya. Kontribusi kelompok dapat menjadi tahan: (a) persepsi terhadap esensi belajar kelompok yang kooperatif (kesadaran kolektif) dan tidak individualistik. Faktor budaya komunal mendukung ini; (b) rasa percaya di antara anggota yang tercipta dari usaha mengenal/menjadi dekat antar anggota; (c) saling bergantung, saling mendukung, saling bekerja sama, saling menolong, dan saling berbagi beban di dalam kelompok; serta (d) tanggung jawab tiap anggota yang diperankan dengan tepat dan proporsional.

Fenomena ketidaktahanan belajar kelompok yang terjadi di sekolah dimaknai sebagai kemampuan suatu kelompok belajar, tidak tahan dalam melaksanakan aktivitas belajar kooperatif, menimbulkan konflik kelompok yang tidak diselesaikan, dan cenderung individualistik sehingga tujuan belajar kelompok menjadi tidak tercapai. Kontribusi ketidaktahanan belajar kelompok yang merupakan faktor pengganggu ketahanan belajar kelompok meliputi, (a) persepsi terhadap esensi belajar kelompok sebagai kompetisi. Orientasi individualistik (egosentrisme) dan akademik mendominasi; (b) sekadar formalitas karena tuntutan sistem sehingga siswa setengah hati membangun kelompok; (c) saling bersaing tanpa peduli kemajuan bersama misalnya, bersikap menentang, mendominasi, mencari muka; (d) pragmatisme belajar yang muncul dari anggota kelompok dengan mendompleng tanggung jawab orang lain.

Setelah ditemukan secara kualitatif, ada kontribusi yang menyebabkan belajar kelompok menjadi tahan ataupun tidak tahan, maka guru maupun praktisi pendidik- an harus memenuhi prasyarat untuk melaksanakan belajar kelompok yang ideal. Misalnya, perlu mendukung hal yang menjadi kontribusi ketahanan belajar kelompok serta meminimalisir kontribusi ketidaktahanan belajar kelompok. Kontribusi-kontribusi tersebut merupakan tesis dalam penelitian tunggal di satu sekolah menengah atas ini. Oleh karena itu, diperlukan variasi penelitian yang lebih luas dan banyak, terkait belajar kelompok dilihat dari sisi ketahanan maupun sebaliknya.

\section{Daftar Pustaka}

Acar, B., \& Tarhan, L. (2007). Effect of cooperative learning strategies on students' understanding of concepts in electrochemistry. International Journal of science and mathematics education, 5(2), 349-373.

Adkinson, J. E. (2007). Does cooperative learning affect girls' and boys' learning and attitudes toward mathematic transformation skills in single -sex and mixed -sex classrooms? (Disertasi doktor, University of South Alabama, 2007). ProQuest Dissertations \& Theses Global. (304762732).

Anggita, D. R. (2014). Dinamika konstruksi nilai kelompok pelajar sekolah menengah atas Yogyakarta (studi fenomenologis konstruksi nilai kelompok pada GNB di SMA Negeri 6 Yogyakarta). Skripsi, tidak diterbitkan, Universitas Gadjah Mada, Yogyakarta.

Barrow, G., Bradshaw, E., \& Newton, T. (2001). Improving behaviour and raising self-esteem in the classroom: A practical guide to using transactional analysis. Great Britain: David Fulton Publisher.

Bogdan, R. \& Taylor, S. J. (1992). Pengantar metode penelitian kualitatif. (Terjemahan Arief Furchan). Surabaya: Usaha Nasional.

Burress, M. D., \& Peters, J. M. (2015). Collaborative Learning in a Japanese Language Course: Student and 
Teacher Experiences. SAGE Open, 5(2). https:// doi.org/10.1177/21582440155 81016

Creswell, J. W. (2015). Penelitian kualitatif $\mathcal{E}$ desain riset: memilih di antara lima pendekatan (Terjemahan Ahmad Lintang Lazuardi). (edisi ketiga). Yogyakarta: Pustaka Pelajar.

Darmadi, H. (2014). Metode penelitian pendidikan dan sosial. Bandung: Penerbit Alfabeta.

Foldnes, N. (2016). The flipped classroom and cooperative learning: evidence from a randomised experiment. Active Learning in Higher Education, 17(1), 3949.

Hammersley, M. (1994). Etnografi ruang kelas: Esai empiris dan metodologis. (Terjemahan Warsono). Semarang: IKIP Semarang Press.

Johnson, D. W., Johnson, R. T., \& Holubec, E. J. (2010). Collaborative Learning: Strategi pembelajaran untuk sukses bersama (Terjemahan Narulita Yusron). Bandung: Nusa Media.

Johnson, S. L. L. (2013). The impact of cooperative and traditional learning on the academic achievement of third grade students in selected rural school districts in Northeast, South Carolina (Disertasi doktor, South Carolina State University, 2013). ProQuest Dissertations \& Theses Global. (1586074629).

Kunandar. (2013). Penilaian autentik (penilaian hasil belajar peserta didik berdasarkan kurikulum 2013). Jakarta: Rajawali Pers.

Langer, G. M., Colton, A. B., \& Goff, L.S. (2003). Collaborative analysis of student work: Improving teaching and learning. Virginia: Association for Supervision and Curriculum Development (ASCD) Publications.

Lewin, K. (1948). Resolving social conflicts: Selected papers on group dynamics. (G.
W. Lewin, Ed.). New York: Harper \& Brothers.

Miarso, Y. (2009). Menyemai benih teknologi pendidikan. Cetakan ke 5. Jakarta: Kencana Prenada Media Group.

Michaelsen, L. K., \& Sweet, M. (2011). Team-based learning. New Directions for Teaching and Learning, 2011(128), 41-51. https://doi.org/10.1002/tl.467

Munir, B. (2001). Dinamika kelompok: Penerapannya dalam laboratorium ilmu perilaku. Palembang: Percetakan Universitas Sriwijaya.

Nam, C. W. (2008). The relative effectiveness of positive interdependence and group processing on student achievement, interaction, and attitude in online cooperative learning (Disertasi doktor, Texas A\&M University, 2008). ProQuest Dissertations \& Theses Global. (288105869).

Pradipta, A. W. \& Sofyan, H. (2015). Implementasi PBL untuk meningkatkan motivasi, kreativitas, dan pemahaman konsep. Jurnal Inovasi Teknologi Pendidikan, 2(1), 32-48.

Raphael, C., Bachen, C. M., \& HernándezRamos, P. F. (2012). Flow and cooperative learning in civic game play. New Media \& Society, 14(8), pp. 1321-1338.

Sanjaya, W. (2010). Strategi pembelajaran berorientasi standar proses pendidikan. Jakarta: Kencana.

Schaefer, R. T. (2012). Sosiologi buku 1. (Terjemahan Anton Novenanto, Diah tantri Dwiandani). Jakarta: Penerbit Salemba Humanika.

Shoval, E., \& Shulruf, B. (2011). Who benefits from cooperative learning with movement activity?. School Psychology International, 32(1), 58-72.

Siswoyo, D. (2008). Ki Hadjar Dewantara: peletak dasar pendidikan nasional. In D. Siswoyo (Ed.), Ilmu Pendidikan (pp. 
163-171). Yogyakarta: UNY Press.

Slavin, R. E. (2009). Cooperative learning:

Teori, riset dan praktik (Terjemahan Lita). London: Allyn dan Bacon.

Stahl, R. J. (Ed.). (1994). Coopetaive learning in social studies: A handbook for teachers. Menlo Park: Addison-Wesley Publishing Company.

Sugiyono. (2011). Metode penelitian kuantitatif kualitatif dan $R \mathcal{E} D$. Bandung: Alfabeta.

Varvarigou, M. (2016). 'I owe it to my group members... Who critically commented on my conducting' cooperative learning in choral conducting education. International Journal of Music Education, 34(1), 116-
130.

Whitener, J. L. (2016). Using the elements of cooperative learning in school band classes in the United States.

International Journal of Music Education, 34 (2) 219-233.

Williams, C. A. (2013). Relative advantage and, simplicity as predictors of the adoption of cooperative learning practices (Disertasi doktor, Welden University, 2013). ProQuest Dissertations \& Theses Global. (1353672107).

Wilson, M. L. (2014). Team-based learning. American Journal of Clinical Pathology, 142(1), 4-4. https:// doi.org/10.1309/AJCPAYGZ DC2ZHS7W 